\title{
New 5-oxomilbemycins from a Genetically Engineered Strain Streptomyces bingchenggensis BCJ60
}

\section{Jiansong $\mathrm{Li}^{1}$, Hui Zhang ${ }^{3}$, Shaoyong Zhang ${ }^{2}$, Haiyan wang ${ }^{1}$, Ji Zhang ${ }^{1}$, Anliang Chen $^{2}$, Jidong Wang ${ }^{2,3^{*}}$ and Wensheng Xiang ${ }^{*}$}

\author{
${ }^{1}$ Life Science and Biotechnology Research Center, School of Life Science, Northeast Agricultural \\ University, Harbin 150030, China \\ ${ }^{2}$ Provincial Joint Engineering Laboratory of Biopesticide Preparation, School of Forestry \& \\ Biotechnology, Zhejiang Agricultural and Forestry University, Lin'An 311300, China \\ ${ }^{3}$ Department of New Drug Screening, Zhejiang Hisun Pharmaceutical Co.,
} Ltd, Taizhou 318000, China

(Received November 21, 2016; Revised May 3, 2017; Accepted May 12, 2017)

\begin{abstract}
Two new 5-oxomilbemycins, 27-aldehyde-5-oxomilbemycin $\beta_{12}$ (1) and 2-hydroxymilbemycin $\mathrm{K}$ (2), were isolated from a genetically engineered strain Streptomyces bingchenggensis BCJ60. Their structures were determined by comprehensive analyses of its ${ }^{1} \mathrm{H}$ and ${ }^{13} \mathrm{C}$ NMR, COSY, HMQC, and HMBC spectroscopic, HRESI-MS mass spectrometric and comparison with data from the literature. Preliminary studies showed that 27aldehyde-5-oxomilbemycin $\beta_{12}$ (1) and 2-hydroxymilbemycin $\mathrm{K}(\mathbf{2})$ possessed strong acaricidal and nematocidal activities.
\end{abstract}

Keywords: New 5-oxomilbemycins; genetically engineered strain; Streptomyces bingchenggensis BCJ60; acaricidal and nematocidal activities. (C) 2017 ACG Publications. All rights reserved.

\section{Introduction}

Milbemycin oxime, 5-oxime derivate of milbemycins A3/A4, is a new semisynthetic macrolide veterinary drug and has been used as a broad-spectrum antiparasitic agent against worms, insects, and mites of pet animals in Japan, USA, Europe, and China [1-3]. Currently, milbemycin oxime is synthesized by a two-step chemical reaction, which involves the ketonization of milbemycins A3/A4 to yield the intermediates 5-oxomilbemycins A3/A4 with chromicanhydride as catalyst [4]. Due to the low efficiency and environmental unfriendliness of the ketonization of milbemycins A3/A4, it is imperative to develop alternative strategies to produce 5-oxomilbemycins A3/A4. In our earlier study, a genetically engineered strain Streptomyces bingchenggensis BCJ60 producing 5-oxomilbemycins as

\footnotetext{
* Corresponding authors: E-Mail: jdwang@ hisunpharm.com; Phone:+86-576-88827216 Fax:+86-576-88828299 xiangwensheng@neau.edu.cn; Phone:+86-451-55190413 Fax:+86-451-55190413
} 
main components was constructed by ARTP mutation system and site-specific genetic engineering cooperatively [5]. Previously, we have reported the isolation and structural elucidation of two new milbemycin derivatives from the genetically engineered strain S. bingchenggensis BCJ60 [6]. To further exploit the active constituents produced by this strain, the detailed fractionation of the crude extract was conducted and two new 5-oxomilbemycins, 27 -aldehyde-5-oxomilbemycin $\beta_{12}(\mathbf{1})$ and 2hydroxymilbemycin K (2) (Figure 1) were subsequently obtained. In this paper, we describe the isolation, structural elucidation, acaricidal and nematocidal activities of compounds $\mathbf{1}$ and $\mathbf{2}$.

\section{Materials and Methods}

\subsection{General}

Optical rotation was measured on a Perkin-Elmer 341 polarimeter (Anton Paar GmbH, Graz, Austria). UV spectra were recorded on a UV-1800 UV spectrophotometer (Shimadzu, Kyoto, Japan). IR spectra were recorded on a Thermo Nicolet Avatar FT-IR spectrophotometer (Thermo, Tokyo, Japan) using $\mathrm{KBr}$ discs. ${ }^{1} \mathrm{H}-\mathrm{NMR}(400 \mathrm{MHz})$ and ${ }^{13} \mathrm{C}-\mathrm{NMR}(100 \mathrm{MHz})$ spectra were measured with a Bruker DRX-400 (Agilent Technologies, Santa Clara, CA, USA) spectrometer. Chemical shifts are reported as parts per million $(\delta)$, using the residual $\mathrm{CHCl}_{3}(\delta(\mathrm{H}) 7.26 ; \delta(\mathrm{C}) 77.0)$ as an internal standard, and coupling constants $(J)$ in hertz. ${ }^{1} \mathrm{H}$ and ${ }^{13} \mathrm{C}-\mathrm{NMR}$ assignments were supported by ${ }^{1} \mathrm{H}-{ }^{1} \mathrm{H}$ COSY, HSQC, and HMBC experiments. The ESI-MS and HRESI-MS were taken on a Q-TOF Micro LC-MS-MS mass spectrometer (Agilent, Boblingen, Germany). Column chromatography (CC) was carried out on silica gel (100-200 mesh, Qingdao Haiyang Chemical Group Co., Qingdao, China). CC fractions were analyzed by TLC (silica gel $\mathrm{GF}_{254}$, Qingdao Marine Chemical Factory, Qingdao, China). Semi-preparative HPLC (Agilent 1100, Zorbax SB-C3, $5 \mu \mathrm{m}, 250 \times 9.4 \mathrm{~mm}$ i.d.; Agilent, Palo Alto, CA, USA) was further performed to obtain pure compounds.

\subsection{Fermentation and Isolation}

The producing strain S. bingchenggensis BCJ60 was maintained on yeast extract-malt (YM) agar slant consisting of sucrose $0.4 \%$, skim milk $0.1 \%$, yeast extract (OXOID Basingstoke, Hampshire, UK) $0.2 \%$, malt extract (BD Biosciences, San Jose, CA, USA) 0.5\%, agar (BD Biosciences) $2.0 \%$ at $28^{\circ} \mathrm{C}$ for $6-8$ days. A seed $15-\mathrm{L}$ fermentor containing $6 \mathrm{~L}$ of seed medium (sucrose $1.0 \%$, polypepton $0.2 \%, \mathrm{~K}_{2} \mathrm{HPO}_{4} 0.05 \%$, skim milk $0.05 \%$ ) was inoculated with $0.5 \mathrm{~L}$ of broth cultured in flask with seed medium. The flask with seed medium $\left(2-6 \times 10^{7}\right.$ spores per $\left.\mathrm{ml}\right)$ was cultured for $30 \mathrm{~h}$ at $28^{\circ} \mathrm{C}$ on a rotary shake at 250 r.p.m. After incubation for $30 \mathrm{~h}$, the seed broth $(6 \mathrm{~L})$ in the $15-\mathrm{L}$ fermentor was transferred into the production $100-\mathrm{L}$ fermentor containing $60-\mathrm{L}$ production medium $(16.0 \%$ sucrose, $2.0 \%$ soybean powder, $0.5 \%$ yeast extract, $0.5 \%$ meat extract, $0.05 \%$ $\mathrm{K}_{2} \mathrm{HPO}_{4}, 0.05 \% \mathrm{MgSO}_{4} \cdot 7 \mathrm{H}_{2} \mathrm{O}, 0.005 \% \mathrm{FeSO}_{4} \cdot 7 \mathrm{H}_{2} \mathrm{O}$ and $0.3 \% \mathrm{CaCO}_{3}$ ). The culture temperature was $28^{\circ} \mathrm{C}$ and the initial $\mathrm{pH}$ was 7.40 sterilized by sparging with steam at $121^{\circ} \mathrm{C}$ for $30 \mathrm{~min}$. The dissolved oxygen was maintained above $35 \%$ by adjusting the agitation speed. The initial aeration and agitation rate in the $15-\mathrm{L}$ reactor was $1 \mathrm{vvm}$ and 180 r.p.m., whereas those in the $100-\mathrm{L}$ were $0.8 \mathrm{vvm}$ and 150 r.p.m., respectively. The fermentation was performed for 10 days at $28^{\circ} \mathrm{C}$.

The fermentation broth $(60 \mathrm{~L})$ was filtered. The resulting cake was washed with water, and both filtrate and wash were discarded. Methanol $(20 \mathrm{~L})$ was used to extract the washed cake. The $\mathrm{MeOH}$ extract was evaporated under reduced pressure to $\sim 3 \mathrm{~L}$ at $50^{\circ} \mathrm{C}$ and the resulting concentrate was extracted three times using an equal volume of EtOAc. The combined EtOAc phase was concentrated under reduced pressure to yield $40 \mathrm{~g}$ of oily substance. The residual oily substance was subjected to a silica gel column chromatography with a gradient petroleum ether/acetone solvent system (from 20:1 to 3:2) to give two fractions (I and II). Fraction II was further fractionated by silica gel eluted with petroleum ether/ethyl acetate $(90: 10,85: 15$, and 80:20, v/v) to give three subfractions (A-C). Subfraction B was separated by semi-preparative HPLC eluting with $\mathrm{CH}_{3} \mathrm{OH} / \mathrm{CH}_{3} \mathrm{CN} / \mathrm{H}_{2} \mathrm{O}$ (42:42:16, $\mathrm{v} / \mathrm{v} / \mathrm{v})$ to afford compounds $\mathbf{1}\left(R_{\mathrm{t}}=18.12 \mathrm{~min}, 13.3 \mathrm{mg}\right)$ and $\mathbf{2}\left(R_{\mathrm{t}}=24.16 \mathrm{~min}, 14.5 \mathrm{mg}\right)$. 
2.3. 27-aldehyde-5-oxomilbemycin $\beta_{12}$ (1). White amorphous powder. $[\alpha]_{D}^{20}+102(c 0.80$, EtOH). UV (EtOH) $\lambda_{\max } \mathrm{nm}(\log \varepsilon): 288$ (4.39), 227 (4.17), 200 (4.30). IR (KBr): 3449, 2927, 1733, 1669, 1451, 1334, 1178, 1057, 1037, 995, $909 \mathrm{~cm}^{-1} .{ }^{1} \mathrm{H}$ NMR (400 MHz, CDCl $)$ and ${ }^{13} \mathrm{C} \mathrm{NMR}(100 \mathrm{MHz}$, $\mathrm{CDCl}_{3}$ ) data are listed in Table 1. ESI-MS: $m / z 525[\mathrm{M}-\mathrm{H}]^{-}$. HR-ESI-MS: $m / z 527.2997[\mathrm{M}+\mathrm{H}]^{+}$ (calcd for $\mathrm{C}_{31} \mathrm{H}_{43} \mathrm{O}_{7}, 527.3003$ ).

2.4. 2-hydroxymilbemycin $K(2)$. White amorphous powder. $[\alpha]_{D}^{20}+91(c 0.40$, EtOH). UV (EtOH) $\lambda_{\max } \mathrm{nm}(\log \varepsilon): 240$ (4.38). IR (KBr): 3440, 2957, 2927, 1696, 1578, 1454, 1378, 1269, 1213, 1060 , $988 \mathrm{~cm}^{-1} .{ }^{1} \mathrm{H}$ NMR $\left(400 \mathrm{MHz}, \mathrm{CDCl}_{3}\right)$ and ${ }^{13} \mathrm{C}$ NMR $\left(100 \mathrm{MHz}, \mathrm{CDCl}_{3}\right)$ data are listed in Table 1. ESI-MS: $m / z 557[\mathrm{M}+\mathrm{H}]^{+}$. HR-ESI-MS: $m / z 574.3357\left[\mathrm{M}+\mathrm{NH}_{4}\right]^{+}$(calcd for $\mathrm{C}_{32} \mathrm{H}_{48} \mathrm{NO}_{8}, 574.3374$ ).

\subsection{Acaricidal activity test}

Each test sample was prepared in acetone at a concentration of $1,000 \mathrm{mg} / \mathrm{L}$ and diluted to the required concentrations of $0.01,0.005,0.0025,0.001$, and $0.0005 \mathrm{mg} / \mathrm{L}$ with distilled water containing alkylphenol ethoxylates $(\sim 1 / 1000, \mathrm{vol} / \mathrm{vol})$. The primary leaves of Vicia faba $\mathrm{L}$. species were infected with $T$. cinnabarinus. At $2 \mathrm{~h}$ after infection, 10 fourth instar mite larvae were dipped in the diluted solutions of related chemicals for $5 \mathrm{~s}$ before the superfluous liquid was removed, and the larvae were kept in a conditioned room. Three replicates were made for each concentration and a blank control. The mortality was evaluated $24 \mathrm{~h}$ after treatment by examining the adult mites under a binocular microscope to determine the living and dead individuals. The $50 \%$ lethal concentrations $\left(\mathrm{LC}_{50} \mathrm{~s}\right)$ of tested compounds were calculated using the probit method.

\subsection{Nematicidal activity test}

About $10 \mu \mathrm{l}$ of each sample was added to an aqueous suspension $(90 \mu \mathrm{l})$ containing approximately 2,500 living nematodes (third instar and fourth instar larvae of Bursaphelenchus xylophilus) per milliliter, and the suspension kept at $25^{\circ} \mathrm{C}$ for $24 \mathrm{~h}$. The blank control group was prepared in the same way but lacked the tested compound. Three replicates were performed in each trial. Finally, the activities of the tested compounds were monitored under a microscope by recording the death rates of nematodes. Nematodes that did not move when prodded with a needle were considered to be dead. The $\mathrm{LC}_{50} \mathrm{~s}$ of tested compounds were calculated using the probit method.

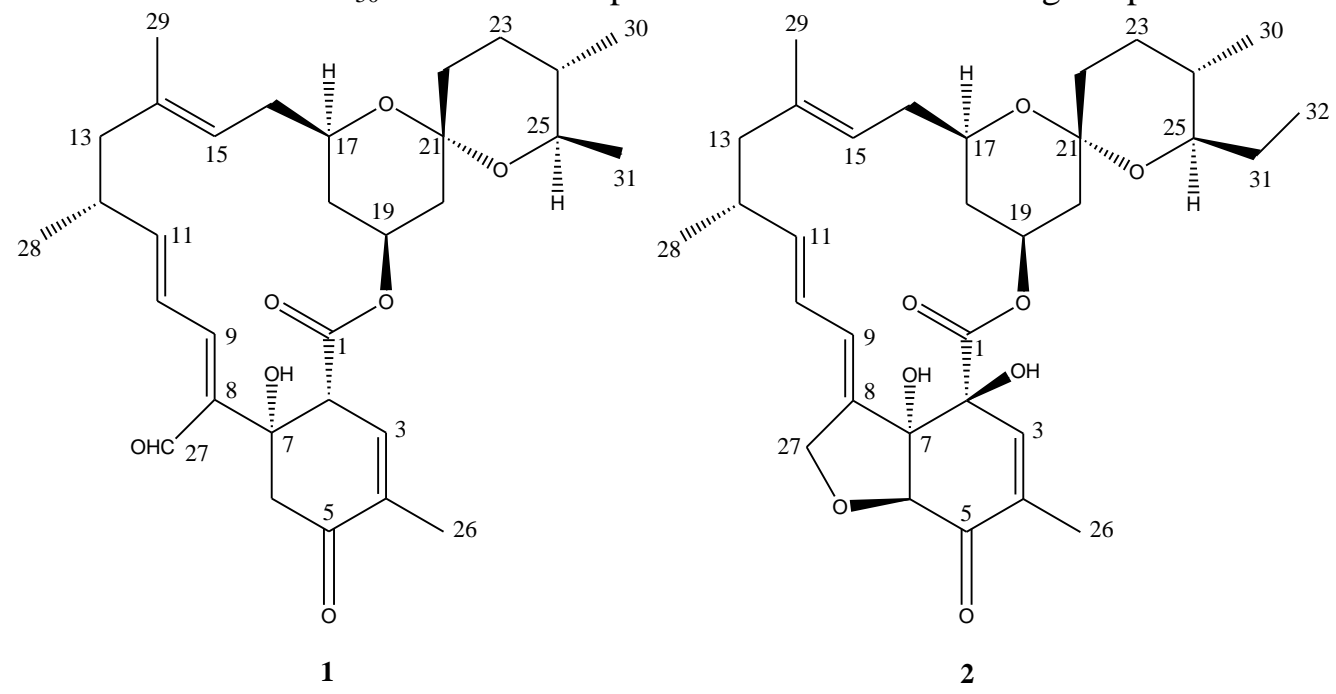

Figure 1. Structures of compounds 1 and 2. 


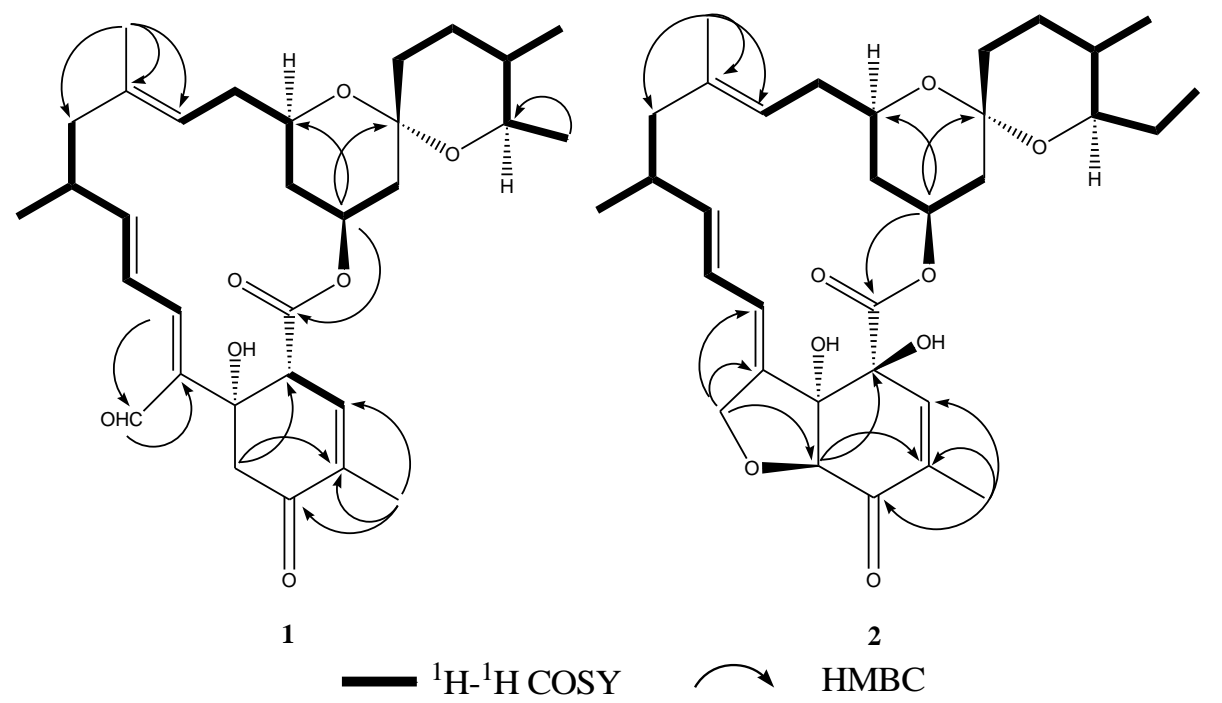

Figure 2. Key ${ }^{1} \mathrm{H}-{ }^{1} \mathrm{H}$ COSY and HMBC correlations of compounds 1 and 2.

\section{Results and Discussion}

\subsection{Structure elucidation}

Compound $\mathbf{1}$ was isolated as a white amorphous powder with a molecular formula $\mathrm{C}_{31} \mathrm{H}_{42} \mathrm{O}_{7}$, as established by HR-ESI-MS at $\mathrm{m} / z$ 527.2997 [M + H] ${ }^{+}$(calcd for $\mathrm{C}_{31} \mathrm{H}_{43} \mathrm{O}_{7}, 527.3003$ ), suggesting 11 degrees of unsaturation. The IR spectrum showed absorptions for hydroxyl group at $3449 \mathrm{~cm}^{-1}$ and carbonyl group at $1669 \mathrm{~cm}^{-1}$. The ${ }^{1} \mathrm{H}$ NMR spectrum (Table 1) revealed five methyls at $\delta_{\mathrm{H}} 0.82(\mathrm{~d}, J=$ $6.5 \mathrm{~Hz}, \mathrm{H}-30), 1.10$ (d, $J=5.6 \mathrm{~Hz}, \mathrm{H}-28), 1.12$ (d, $J=6.0 \mathrm{~Hz}, \mathrm{H}-31), 1.61$ (s, H-29), and 1.86 (s, H26); one trans-double bond at $\delta_{\mathrm{H}} 5.86(\mathrm{dd}, J=10.2,14.2 \mathrm{~Hz}, \mathrm{H}-11)$ and $6.79(\mathrm{dd}, J=12.1,14.2 \mathrm{~Hz}, \mathrm{H}-$ 10); one aldehyde at $\delta_{\mathrm{H}} 10.22$ (s, H-27). Detailed analysis of the NMR data indicated the presence of 31 carbon signals, which were classified as five methyls $\left(\delta_{\mathrm{C}} 15.7,16.0,17.8,19.3\right.$ and 21.2), seven methylenes $\left(\delta_{\mathrm{C}} 27.7,34.5,35.6,36.6,40.7,47.6\right.$ and 48.6$)$, six aliphatic methines $\left(\delta_{\mathrm{C}} 36.5,36.6,48.6\right.$, 67.2, 69.1 and 71.4), one oxygenated quaternary carbon $\left(\delta_{\mathrm{C}} 75.7\right)$, one ketal carbon $\left(\delta_{\mathrm{C}} 97.5\right)$, eight $s p^{2}$ carbons $\left(\delta_{\mathrm{C}} 121.4,121.5,135.4,136.2,136.3,136.7,148.3\right.$, and 153.5$)$, one aldehyde $\left(\delta_{\mathrm{C}} 189.3\right)$, an ester carbonyl $\left(\delta_{\mathrm{C}} 173.0\right)$, as well as one carbonyl group $\left(\delta_{\mathrm{C}} 196.6\right)$. The ${ }^{1} \mathrm{H}-{ }^{1} \mathrm{H}$ COSY NMR spectrum (Figure 2) of 1 displayed a series of correlations: $\mathrm{H}-9$ to $\mathrm{H}_{3}-28, \mathrm{H}-15$ to $\mathrm{H}_{2}-20$, and $\mathrm{H}_{2}-22$ to $\mathrm{H}_{3}-31$. The HMBC correlations from $\mathrm{H}_{3}-26\left(\delta_{\mathrm{H}} 1.86\right)$ to C-3 $\left(\delta_{\mathrm{C}} 136.2\right), \mathrm{C}-4\left(\delta_{\mathrm{C}} 136.7\right)$ and C-5 $\left(\delta_{\mathrm{C}} 196.6\right)$, from $\mathrm{H}_{3}-29\left(\delta_{\mathrm{H}} 1.61\right)$ to $\mathrm{C}-13\left(\delta_{\mathrm{C}} 48.1\right), \mathrm{C}-14\left(\delta_{\mathrm{C}} 136.3\right)$ and $\mathrm{C}-15\left(\delta_{\mathrm{C}} 121.5\right)$, and from $\mathrm{H}-19\left(\delta_{\mathrm{H}} 5.35\right)$ to $\mathrm{C}-1\left(\delta_{\mathrm{C}} 173.0\right), \mathrm{C}-17\left(\delta_{\mathrm{C}} 67.2\right)$ and C-21 $\left(\delta_{\mathrm{C}} 97.5\right)$ were observed. Analysis of the ${ }^{1} \mathrm{H}-{ }^{1} \mathrm{H}$ COSY, HSQC and HMBC spectra assigned the ${ }^{1} \mathrm{H}$ NMR and ${ }^{13} \mathrm{C}$ NMR data as shown in Table 1 and revealed compound 1 possessed the same macrocyclic lactone skeleton as 5-oxomilbemycin A3 (milbemycin J) [7-9] and milbemycin $\beta_{12}$ [10]. Differences between compound 1 and 5-oxomilbemycin A3 were that the furan ring was missing and instead a C-27 aldehyde group was present in 1. In addition, the C-6 oxygenated methine in 5-oxomilbemycin A3 was replaced by a methylene group in $\mathbf{1}$. The differences between compound $\mathbf{1}$ and milbemycin $\beta_{12}$ were that an aldehyde group and a carbonyl group were situated at $\mathrm{C}-27$ and $\mathrm{C}-5$, respectively, in $\mathbf{1}$. The observed $\mathrm{HMBC}$ correlations from $\mathrm{H}-9\left(\delta_{\mathrm{H}} 7.39\right)$ to C-27 $\left(\delta_{\mathrm{C}} 189.3\right)$, from $\mathrm{H}-27(10.22)$ to $\mathrm{C}-8\left(\delta_{\mathrm{C}} 135.4\right)$, from $\mathrm{H}-6\left(\delta_{\mathrm{H}} 2.40,3.38\right)$ to C-2 $\left(\delta_{\mathrm{C}} 48.6\right)$, C-4 $\left(\delta_{\mathrm{C}} 136.7\right)$, and from $\mathrm{H}_{3}-26\left(\delta_{\mathrm{H}} 1.86\right)$ to $\mathrm{C}-3\left(\delta_{\mathrm{C}} 136.2\right), \mathrm{C}-4\left(\delta_{\mathrm{C}} 136.7\right)$ and $\mathrm{C}-5\left(\delta_{\mathrm{C}} 196.6\right)$ supported the structural assignment of compound 1. Therefore, the planar structure of compound 1 was elucidated and named 27-aldehyde-5-oxomilbemycin $\beta_{12}$. The relative configuration of 1 was assigned as occurring with 5-oxomilbemycins A3/A4. 
Compound 2 had the molecular formula $\mathrm{C}_{32} \mathrm{H}_{44} \mathrm{O}_{8}$ and 11 degrees of unsaturation, as deduced from HR-ESI-MS $m / z 574.3357\left[\mathrm{M}+\mathrm{NH}_{4}\right]^{+}$(calcd for $\mathrm{C}_{32} \mathrm{H}_{48} \mathrm{NO}_{8}$, 574.3374). The IR absorption bands revealed the presence of hydroxyl $\left(3440 \mathrm{~cm}^{-1}\right)$ and carbonyl $\left(1696 \mathrm{~cm}^{-1}\right)$ functionalities. The ${ }^{1} \mathrm{H}$ NMR spectrum (Table 1) indicated the presence of five methyls at $\delta_{\mathrm{H}} 0.83(\mathrm{~d}, J=8.0 \mathrm{~Hz}, \mathrm{H}-30), 1.03$ (d, $J=6.4 \mathrm{~Hz}, \mathrm{H}-28), 1.04$ (t, $J=6.4 \mathrm{~Hz}, \mathrm{H}-32), 1.55$ (br s, H-29) and 1.97 (s, H-26), one trans-double bond at $\delta_{\mathrm{H}} 5.50(\mathrm{dd}, J=10.0,14.5 \mathrm{~Hz}, \mathrm{H}-11)$ and $5.82(\mathrm{dd}, J=11.6,14.5 \mathrm{~Hz}, \mathrm{H}-10)$. The ${ }^{13} \mathrm{C}$ NMR (Table 1) and DEPT spectra showed 32 carbon signals, including five methyls $\left(\delta_{\mathrm{C}} 10.1,15.5,15.7\right.$, 17.7, and 22.3), eight methylenes $\left(\delta_{\mathrm{C}} 25.7,27.8,34.5,35.5,36.5,41.3,48.3\right.$, and 70.8), five aliphatic methines $\left(\delta_{\mathrm{C}} 34.2,35.7,67.5,71.1\right.$, and 76.1$)$, three oxygenated quaternary carbons $\left(\delta_{\mathrm{C}} 75.0,81.7\right.$. $82.8)$, one ketal carbon $\left(\delta_{\mathrm{C}} 97.5\right)$, eight $s p^{2}$ carbons $\left(\delta_{\mathrm{C}} 121.0,123.4,123.6,137.2,137.3,138.8,140.3\right.$, and 144.7), an ester carbonyl $\left(\delta_{\mathrm{C}} 171.4\right)$, and one carbonyl group $\left(\delta_{\mathrm{C}} 194.2\right)$. The comparison of the spectral data of compound 2 and 5-oxomilbemycin A4 (milbemycin K) [7-9] showed a close similarity, except for the absence of a methine group (C-2 in 5-oxomilbemycin A4) in 2. Instead, an oxygenated quaternary carbon $\left(\delta_{\mathrm{C}} 75.0, \mathrm{C}-2\right)$ was observed in 2 . Considered the molecular formula, a hydroxy group was situated at C-2. The HMBC correlations from H-6 to C-2 and C-4 further confirmed the assignment. Compound 2, therefore, was established and named 2-hydroxymilbemycin $\mathrm{K}$. The relative configuration of $\mathrm{C}-2-\mathrm{OH}$ was attempted to assign as that of 2-hydroxy-3,4-dihydro-avermectin $\mathrm{B}_{1}$ [11]. The other chiral centers of 2 were assigned as analogs to 5-oxomilbemycins A3/A4 [5].

\subsection{Acaricidal and nematocidal capacities}

The acaricidal and nematocidal capacities of compounds $\mathbf{1}$ and $\mathbf{2}$ were evaluated against Tetranychus cinnabarinus and Bursaphelenchus xylophilus, respectively [12-13]. The mixture of commercial acaricide and nematocide milbemycins A3/A4 was used as a positive control. As shown in Table 2, although compounds $\mathbf{1}$ and $\mathbf{2}$ exhibited strong acaricidal and nematocidal capacities, the bioactivities were weaker than those of milbemycins A3/A4, and this result will encourage us to further investigate the derivatives of milbemycin as the insecticidal agents in future.

Milbemycins have 16-membered macrolide structures, which are biosynthesized via a polyketide derived from the condensation of several units of acetate, propionate and branched-chain fatty acid [14]. The first reported members of the family, milbemycins, $\alpha_{1}$ to $\alpha_{10}$ and $\beta_{1}$ to $\beta_{3}$ were isolated from Streptomyces hygroscopicus subsp. aureolacrimosus [15]. Subsequently, a further series of milbemycins ( $\alpha_{11}$ to $\alpha_{27}$ and $\beta_{4}$ to $\beta_{12}$ ) were described from Streptomyces cyaneogriseus subsp. noncyanogenus and Streptomyces thermoarchaensis [16]. Apart from the mentioned strains, another newly milbemycin-producing strain Streptomyces bingchenggensis was isolated by our research team and currently used as an industrial producer of milbemycins [17]. S. bingchenggensis produces milbemycins A3/A4, two $\alpha$-class milbemycins (B2/B3) and two $\beta$-class milbemycins $\left(\beta_{1} / \beta_{2}\right)$ as its major components together with the polyether ionophore nanchangmycin and a trace of new milbemycin analogs, including $\alpha_{28}, \alpha_{29}, \alpha_{30}, \beta_{13}, \beta_{14}$, ST906, and secomilbemycins A and B $[18,19]$. The $\alpha$-class milbemycins with the furan ring at C-27 was generally associated with better acaricidal and nematocidal capacities than the $\beta$-class. Compounds $\mathbf{1}$ and $\mathbf{2}$ belong to $\beta$-class and $\alpha$-class milbemycins, respectively. However, the nematocidal activity of compound $\mathbf{1}$ was superior to that of compound 2. Maybe the aldehyde moiety at C-27 position was possible to improve the nematocidal activity. 
Table 1. ${ }^{1} \mathrm{H}$ and ${ }^{13} \mathrm{C}$ NMR data (400 and $100 \mathrm{MHz}$, resp.) of compounds $\mathbf{1}$ and $\mathbf{2}$ in $\mathrm{CDCI}_{3}$.

\begin{tabular}{|c|c|c|c|c|}
\hline \multirow{2}{*}{ position } & \multicolumn{2}{|c|}{$\delta_{\mathrm{H}}$} & \multicolumn{2}{|c|}{$\delta_{\mathrm{C}}$} \\
\hline & 1 & 2 & 1 & 2 \\
\hline 1 & & & 173.0 & 171.4 \\
\hline 2 & $4.28(1 \mathrm{H}, b r s)$ & & 48.6 & 75.0 \\
\hline 3 & $6.38(1 \mathrm{H}, b r s)$ & $6.79(1 \mathrm{H}, s)$ & 136.2 & 140.3 \\
\hline 4 & & & 136.7 & 137.3 \\
\hline 5 & & & 196.6 & 194.2 \\
\hline \multirow[t]{2}{*}{6} & $2.40(1 \mathrm{H}, m)$ & $4.11(1 \mathrm{H}, s)$ & 47.6 & 82.8 \\
\hline & $3.38(1 \mathrm{H}, m)$ & & & \\
\hline 7 & & & 75.7 & 81.7 \\
\hline 8 & & & 135.4 & 138.8 \\
\hline 9 & $7.39(1 \mathrm{H}, d, J=12.1)$ & $5.92(1 \mathrm{H}, d, J=11.6)$ & 148.3 & 123.6 \\
\hline 10 & $6.79(1 \mathrm{H}, d d, J=14.2,12.1)$ & $5.82(1 \mathrm{H}, d d, J=11.6,14.5)$ & 121.4 & 123.4 \\
\hline 11 & $5.86(1 \mathrm{H}, d d, J=14.2,10.2)$ & $5.50(1 \mathrm{H}, d d, J=14.5,10.0)$ & 153.5 & 144.7 \\
\hline 12 & $2.58(1 \mathrm{H}, m)$ & $2.48(1 \mathrm{H}, m)$ & 36.6 & 35.7 \\
\hline \multirow[t]{2}{*}{13} & $1.95(1 \mathrm{H}, m)$ & $1.92(1 \mathrm{H}, m)$ & 48.1 & 48.3 \\
\hline & $2.23(1 \mathrm{H}, m)$ & $2.24(1 \mathrm{H}, m)$ & & \\
\hline 14 & & & 136.3 & 137.2 \\
\hline 15 & $4.88(1 \mathrm{H}, b r d, J=10.1)$ & $5.01(1 \mathrm{H}, t, J=6.8)$ & 121.5 & 121.0 \\
\hline 16 & $2.24(2 \mathrm{H}, m)$ & $2.27(2 \mathrm{H}, m)$ & 34.5 & 34.5 \\
\hline 17 & $3.57(1 \mathrm{H}, m)$ & $3.61(1 \mathrm{H}, m)$ & 67.2 & 67.5 \\
\hline \multirow[t]{2}{*}{18} & $1.69(1 \mathrm{H}, m)$ & $1.93(1 \mathrm{H}, m)$ & 36.6 & 36.5 \\
\hline & $0.73(1 \mathrm{H}, m)$ & $1.05(1 \mathrm{H}, q, J=11.2)$ & & \\
\hline 19 & $5.34(1 \mathrm{H}, m)$ & $5.59(1 \mathrm{H}, m)$ & 69.1 & 71.1 \\
\hline \multirow[t]{2}{*}{20} & $1.94(1 \mathrm{H}, m)$ & $2.05(1 \mathrm{H}, m)$ & 40.7 & 41.3 \\
\hline & $1.39(1 \mathrm{H}, m)$ & $1.49(1 \mathrm{H}, t, J=11.8)$ & & \\
\hline 21 & & & 97.5 & 97.5 \\
\hline \multirow[t]{2}{*}{22} & $1.53(1 \mathrm{H}, m)$ & $1.53(1 \mathrm{H}, m)$ & 35.6 & 35.5 \\
\hline & $1.65(1 \mathrm{H}, m)$ & $1.70(1 \mathrm{H}, m)$ & & \\
\hline 23 & $1.53(2 \mathrm{H}, m)$ & $1.55(2 \mathrm{H}, m)$ & 27.7 & 27.8 \\
\hline 24 & $1.26(1 \mathrm{H}, m)$ & $1.35(1 \mathrm{H}, m)$ & 36.5 & 34.2 \\
\hline 25 & $3.23(1 \mathrm{H}, m)$ & $3.12(1 \mathrm{H}, m)$ & 71.4 & 76.1 \\
\hline 26 & $1.86(3 \mathrm{H}, s)$ & $1.97(3 \mathrm{H}, s)$ & 15.7 & 15.7 \\
\hline 27 & $10.22(1 \mathrm{H}, s)$ & $4.72(2 \mathrm{H}, s)$ & 189.3 & 70.8 \\
\hline 28 & $1.10(3 \mathrm{H}, d, J=5.6)$ & $1.03(3 \mathrm{H}, d, J=6.4)$ & 21.2 & 22.3 \\
\hline 29 & $1.61(3 \mathrm{H}, s)$ & $1.55(3 \mathrm{H}, s)$ & 16.0 & 15.5 \\
\hline 30 & $0.82(3 \mathrm{H}, d, J=6.5)$ & $0.83(3 \mathrm{H}, d, J=8.0)$ & 17.8 & 17.7 \\
\hline \multirow[t]{2}{*}{31} & $1.12(3 \mathrm{H}, d, J=6.0)$ & $1.39(1 \mathrm{H}, m)$ & 19.3 & 25.7 \\
\hline & & $1.73(1 \mathrm{H}, m)$ & & \\
\hline 32 & & $1.04(3 \mathrm{H}, t, J=6.4)$ & & 10.1 \\
\hline
\end{tabular}


Table 2. Acaricidal and nematocidal activities of compounds $\mathbf{1}$ and $\mathbf{2}$.

\begin{tabular}{cccccc}
\hline & \multicolumn{2}{c}{ Tetranychus cinnabarinus } & & \multicolumn{2}{c}{ Bursaphelenchus xylophilus } \\
Compounds & $\mathrm{LC}_{50}(\mathrm{mg} / \mathrm{L})^{\mathrm{b}}$ & $P$-value $^{\mathrm{c}}$ & & $\mathrm{LC}_{50}(\mathrm{mg} / \mathrm{L})^{\mathrm{b}}$ & $P_{\text {-value }}^{\mathrm{c}}$ \\
\hline $\mathbf{1}$ & $0.197 \pm 0.006$ & 0.001 & & $6.794 \pm 1.058$ & 0.215 \\
$\mathbf{2}$ & $0.168 \pm 0.005$ & 0.002 & & $7.852 \pm 0.116$ & 0.001 \\
milbemycins A3/A4 & $0.107 \pm 0.006$ & - & & $4.897 \pm 0.042$ & - \\
\hline
\end{tabular}

${ }^{\mathrm{a}}$ Milbemycins A3 and A4 mixtures, 30:70 (in volume).

${ }^{\mathrm{b}}$ Values are the means \pm SDs of three independent experiments.

${ }^{\mathrm{c}} P$-values are obtained by compared with milbemycins A3/A4 using Student's $t$-test.

\section{Acknowledgments}

This research was financially supported by grants from the National Outstanding Youth Foundation (No. 31225024), the National Natural Science Foundation of China (No. 31471832, 31171913, 31500010, 31572070 and 31372006), the National Key Technology R\&D Program (No. 2012BAD19B06) and Chang Jiang Scholar Candidates Program for Provincial Universities in Heilongjiang (CSCP).

\section{Supporting Information}

Supporting Information accompanies this paper on http://www.acgpubs.org/RNP

\section{References}

[1] S. E. Bienhoff, D. J. Kok, L. M. Roycroft and E. S. Roberts (2013). Efficacy of a single oral administration of milbemycin oxime against natural infections of Ancylostoma braziliense in dogs, Vet. Parasitol. 195, 102-105.

[2] R. Schenker, D. Bowman, C. Epe, R. Cody, W. Seewald, G. Strehlau and P. Junquera (2007). Efficacy of a milbemycin oxime-praziquantel combination product against adult and immature stages of Toxocara cati in cats and kittens after induced infection, Vet. Parasitol. 145, 90-93.

[3] J. W. McCall (2005). The safety-net story about macrocyclic lactone heartworm preventives: A review, an update, and recommendations, Vet. Parasitol. 133, 197-206.

[4] Y. Tsukamoto, K. Sato, S. Mio, S. Sugai, T. Yanai, N. Kitano, S. Muramatsu and Y. Nakada, J. Ide (1991). Synthesis of 5-keto-5-oxime derivatives of milbemycins and their activities against microfilariae, Agric. Biol. Chem. 55, 2615-2621.

[5] H. Y. Wang, J. Zhang, Y. J. Zhang, B. Zhang, C. X. Liu, H. R. He, X. J. Wang and X. S. Xiang (2014). Combined application of plasma mutagenesis and gene engineering leads to 5-oxomilbemycins A3/A4 as main components from Streptomyces bingchenggensis, Appl. Microbiol. Biot. 98, 9703-9712.

[6] J. S. Li, M. N. Du, H. Zhang, J. Zhang, S. Y. Zhang, H. Y. wang, A. L. Chen, J. D. Wang and W. S. Xiang (2017). New milbemycin metabolites from a genetically engineered strain Streptomyces bingchenggensis BCJ60, Nat. Prod. Res. 31(7), 780-784.

[7] H. Mishima, J. Ide, S. Muramatsu, M. Ono (1983). Milbemycins, a new family of macrolide antibiotics. Structure determination of milbemycins D, E, F, G, H, J and K, J. Antibiot. 36, 980-990.

[8] S. V. Ley, A. Madinb and N. J. T. Moncka (1993). Total synthesis of the spiroketal macrolide (+) milbemycin $\alpha_{1}$, Tetrahedron Lett. 34, 7479-7482. 
[9] Y. Tsukamoto, K. Sato, S. Mio, S. Sugai, T. Yanai, N. Kitano, S. Muramatsu, Y. Nakada and J. Ide (1991) Synthesis of 5-keto-5-oxime derivatives of milbemycins and their activities against microfilariae, Agric. Biol. Chem. 55, 2615-2621.

[10] N. Nonaka, T. Tsukiyama, Y. Okamoto, K. Kazuo Sato, C. Kumasaka, T. Yamamoto, F. Maruyama and H. Yoshikawa (2000). New Milbemycins from Streptomyces hygroscopicus subsp. aureolacrimosus: Fermentation, Isolation and Structure Elucidation, J. Antibiot. 73, 694-704.

[11] J. Cassayre, T. Winkler, T. Pitterna and L. Quaranta (2010). Application of Mn(III)-catalysed olefin hydration reaction to the selective functionalisation of avermectin B1, Tetrahedron Lett. 51, 1706-1709.

[12] J. Huang, A. L. Chen, H. Zhang, Z. Yu, M. H. Li, N. Li, J. T. Lin, H. Bai, J. D. Wang and Y. G. Zheng (2015). Gene replacement for the generation of designed novel avermectin derivatives with enhanced acaricidal and nematicidal activities, Appl. Environ. Microb. 81, 5326-5334.

[13] J. J. Pan, X. Wan, H. Zhang, Z. Chen, J. Huang, B. Yang, A. L. Chen and J. D. Wang (2016). Three new milbemycins from a genetically engineered strain S. avermitilis MHJ1011, J. Antibiot. 69, 104-107.

[14] K. Tanaka, H. Yoshikawa, M. Ando, S. Katsumi, K. Matsumoto, T. Toyama, M. Shibano and M. Abe (1993). Milbemycin: discovery and development, Annu. Rep. Sankyo Res. Lab. 45, 1-98.

[15] Y. Takiguchi, H. Mishima, M. Okuda and M. Terao (1980). Milbemycin, a new family of macrolide antibiotics: fermentation, isolation and physicochemical properties, J. Antibiot. 33, 1120-1127.

[16] J. D. Hood, R. M. Banks, M. D. Brewer, J. P. Fish, B. R. Manger and M. E. Poulton (1989). A novel series of milbemycin antibootics from Streptomyces strain E225. 1. Discovery, fermentation and anthelmintic activity, J. Antibiot. 42, 1593-1598.

[17] X. J. Wang, X. C. Wang and W. S. Xiang (2009). Improvement of milbemycin producing Streptomyces bingchenggensis by rational screening of ultraviolet-and chemically induced mutants, World J. Microbiol. Biotechnol. 25, 1051-1056.

[18] J. Zhang, J. An, J. J. Wang, Y. J. Yan, H. R. He, X. J. Wang and W. S. Xiang (2013). Genetic engineering of Streptomyces bingchenggensis to produce milbemycins A3/A4 as main components and eliminate the biosynthesis of nanchangmycin, Appl. Microbiol. Biotechnol. 97, 10091-10101.

[19] W. S. Xiang, J. D. Wang, X. J. Wang and J. Zhang (2009), A novel macrolide compound from Streptomyces bingchenggensis: fermentation, isolation, structure elucidation and biological properties, J. Antibiot. 62, 229-231.

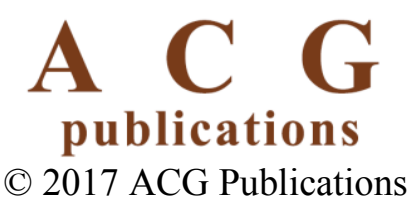

